Boston University School of Law

Scholarly Commons at Boston University School of Law

Faculty Scholarship

2006

Intelligent Judging: Evolution in the Classroom and the Courtroom

George J. Annas

Follow this and additional works at: https://scholarship.law.bu.edu/faculty_scholarship

Part of the Health Law and Policy Commons 


\title{
Intelligent Judging - Evolution in the Classroom and the Courtroom
}

\author{
George J. Annas, J.D., M.P.H.
}

Religious arguments have permeated debates on the role of the law in medical practice at the beginning and the end of life. But nowhere has religion played so prominent a role as in the century-old quest to banish or marginalize the teaching of evolution in science classes. Nor has new genetics research that supports evolutionary theory at the molecular level dampened antievolution sentiment. ${ }^{1}$ Requiring public-school science teachers to teach specific religion-based alternatives to Darwin's theory of evolution is just as bad, in the words of political comedian Bill Maher, as requiring obstetricians to teach medical students the alternative theory that storks deliver babies. Nonetheless, stork lore is not religious lore, and the central constitutional objection to banning evolution from the public-school curriculum or marginalizing it is that this would violate the "establishment clause" of the First Amendment, which provides that "Congress shall make no law respecting an establishment of religion, or prohibiting the free exercise thereof." The United States has had two waves of religion-inspired antievolution activism, and a decision by U.S. District Court Judge John E. Jones III made just before Christmas 2005 marks the end of the third wave. ${ }^{2}$

THE FIRST WAVE - OUTLAWING EDUCATION ABOUT EVOLUTION

In 1925, Tennessee adopted a law that made it a crime for any public-school teacher to "teach any theory that denies the story of divine creation of man as taught in the Bible and to teach instead that man has descended from a lower order of animals." In that same year, John Thomas Scopes was tried and convicted of violating this law in one of the most famous trials of the 20th century, dramatized in the play Inherit the Wind (1955) and the film based on the play (1960). Scopes was prosecuted by the eloquent three-time presidential candidate William Jennings Bryan and defended by Clarence Darrow. The journalist H.L. Mencken described the prosecution as a religious attack on an alleged "conspiracy of scientists . . . to break down religion, propagate immorality, and reduce mankind to the level of the brute." On appeal of the conviction, the Tennessee Supreme Court concluded that the statute was constitutional, because it could find "no unanimity among the members of any religious establishment" about evolution. The court nevertheless reversed Scopes's conviction on a technicality and instructed the state attorney general not to try Scopes again, saying, "We see nothing to be gained by prolonging the life of this bizarre case."

In 1928, Arkansas legislators passed a law they believed would better withstand a First Amendment challenge. The Arkansas law simply made it a crime "to teach the theory or doctrine that mankind ascended or descended from a lower order of animals." This "monkey law" was challenged in the mid-1960s by a young high-school biology teacher, who had obtained an injunction against its enforcement. On appeal, the Arkansas Supreme Court reversed and lifted the injunction in a twosentence opinion, finding the law "a valid exercise of the state's power." The case then went to the U.S. Supreme Court, where the Arkansas law was declared unconstitutional as a violation of the First Amendment, because it furthered no secular purpose, only a religious one:

The overriding fact is that Arkansas law selects from the body of knowledge a particular segment when it proscribes for the sole reason that it is deemed to conflict with a particular religious doctrine: that is, with a particular interpretation of the Book of Genesis by a particular religious group. . . . 
Government in our democracy, state and national, must be neutral in matters of religious theory, doctrine, and practice. ${ }^{4}$

THE SECOND WAVE - CREATIONISM

The First Amendment prohibits the state from establishing religion. To withstand a First Amendment challenge on this basis, the state must satisfy three tests: the law must have a secular purpose, have a primarily secular effect, and not require excessive government entanglement in religion. ${ }^{5}$ Arkansas attempted to meet these tests when it enacted a 1981 law that did not require any direct teaching of the Bible, but only that "public schools . . . give balanced treatment to creation-science and to evolution-science." ${ }^{6}$ The Arkansas statute defined creation science as the following:

the scientific evidence and related inferences that indicate: (1) sudden creation of the universe, energy, and life from nothing; (2) the insufficiency of mutation and natural selection in bringing about development of all living kinds from a single organism; (3) changes only within fixed limits of originally created kinds of plants and animals; (4) separate ancestry for man and apes; (5) explanation of the earth's geology by catastrophism, including the occurrence of a world wide flood; and (6) a relatively recent inception of the earth and living kinds. ${ }^{7}$

Federal judge William R. Overton, in a detailed opinion, concluded in 1982 that this definition was based on the Bible and that the ideas in the definition "are not similar to the literal interpretation of Genesis; they are identical and parallel to no other story of creation." ${ }^{7}$ Those challenging the law also argued that creation science was not science at all in that it lacked all the essential characteristics of science - its conclusions had to be taken on faith and were not tentative, testable, or falsifiable. Overton found the law unconstitutional because its purpose was religious, not secular. ${ }^{7}$

Shortly thereafter, a similar law, the 1982 Louisiana "Creationism Act," reached the Supreme Court in the case of Edwards v. Aguillard. ${ }^{8}$ The act forbade the teaching of evolution in public schools unless accompanied by instruction in "creation science." The Court struck down the law, because it had a religious purpose: "to advance the religious viewpoint that a supernatural creator was responsible for the creation of humankind." The Court concluded:

The Louisiana Creationism Act advances a religious doctrine by requiring either the banishment of the theory of evolution from public school classrooms or the presentation of a religious viewpoint that rejects evolution in its entirety. The Act violates the Establishment Clause of the First Amendment because it seeks to employ the symbolic and financial support of government to achieve a religious purpose. ${ }^{8}$

This decision ended the short life of teaching creationism in the public schools and ushered in the third wave of antievolution sentiment: intelligent design.

THE THIRD WAVE -

INTELLIGENT DESIGN

Understanding that it was a violation of the First Amendment for the state either to ban the teaching of evolution outright (first wave) or to require the teaching of "creationism" when evolution was taught (second wave), antievolutionists adopted a new strategy - to expose unresolved problems in the theory of evolution and require that other theories, including one called "intelligent design," also be taught. The Discovery Institute established its Center for Science and Culture to challenge Darwin's theory and promote the inclusion of intelligent design in school curricula nationwide. President George W. Bush entered this debate, saying in August 2005 that when he was the governor of Texas, "he felt like both sides ought to be properly taught," and that today, "if you're asking me whether or not people ought to be exposed to different ideas, the answer is yes."

The first legal challenge to requiring the teaching of intelligent design with evolution involved the tiny Dover Area School District, in Pennsylvania, and the case was decided in December 2005.2 It involved two primary questions. First, is intelligent design a science (or is it just creationism under another name)? And second, does requir- 
ing the teaching of intelligent design in science classes amount to a governmental endorsement of religion or serve a religious purpose?

U.S. District Court Judge John E. Jones III, a Republican appointed to the court by President George W. Bush, presided over a six-week trial during which he heard evidence from members of the school board, scientists, and proponents of intelligent design, among others. At issue was the constitutionality, under the establishment clause of the First Amendment, of two actions taken by the Dover Area School Board. The first was a strangely worded October 2004 resolution, passed by the school board by a vote of six to three: "Students will be made aware of gaps or problems in Darwin's theory and of other theories of evolution, including, but not limited to, intelligent design. Note: Origins of Life is not taught." The next month, the school district announced in a press release that beginning in January 2005, teachers would be required to read the following statement to students in the ninth-grade biology class at Dover High School:

The Pennsylvania Academic Standards require students to learn about Darwin's Theory of Evolution and eventually to take a standardized test of which evolution is a part. Because Darwin's Theory is a theory, it continues to be tested as new evidence is discovered. The Theory is not a fact. Gaps in the theory exist for which there is no evidence. A theory is defined as a well-tested explanation that unifies a broad range of observations. Intelligent Design is an explanation of the origin of life that differs from Darwin's view. The reference book, of Pandas and People, is available for students who might be interested in gaining an understanding of what Intelligent Design actually involves. With respect to any theory, students are encouraged to keep an open mind. The school leaves the discussion of Origins of Life to individual students and their families. As a Standards-driven district, class instruction focuses upon preparing students to achieve proficiency on Standards-based assessments. ${ }^{2}$

The court heard extensive testimony about whether intelligent design qualifies as science and whether intelligent design took into consideration that there could be any other intelligent designer than God. The petitioners introduced into evidence early drafts of the book on intelligent design referred to by the Dover School Board, OfPandas and People, some of which had been written before Edwards v. Aguillard and some of it after the opinion had been rendered. This evidence helped to persuade Judge Jones that intelligent design was just a new term for creationism:

By comparing the pre and post Edwards drafts of Pandas, three astonishing points emerge: (1) the definition for creation science in the early drafts is identical to the definition of ID [intelligent design]; (2) cognates of the word creation (creationism and creationist) which appeared approximately 150 times were deliberately and systematically replaced with the phrase ID; and (3) the changes occurred shortly after the Supreme Court held that creation science is religious and cannot be taught in public school science classes in Edwards. ${ }^{2}$

The judge concluded that "this compelling evidence strongly supports plaintiff's assertion that ID is creationism re-labeled." The judge could have stopped there but decided instead to answer the question of whether intelligent design is science, stating:

After a six week trial that spanned twentyone days and included countless hours of detailed expert witness presentation, the court is confident that no other tribunal in the United States is in a better position than are we to traipse into this controversial area [and] . . . in the hope that it may prevent the obvious waste of judicial and other resources which would be occasioned by a subsequent trial involving the precise question which is before us. ${ }^{2}$

Judge Jones summarized the expert testimony in more than 25 pages, concluding that it demonstrated to him that intelligent design is "an interesting theological argument" but is not science for many reasons: it invokes a supernatural cause; it relies on the same flawed arguments as creationism; its attacks on evolution have been refuted by the scientific community; it has failed to gain acceptance in the scientific community; 
it has not generated any peer-reviewed publications; and it has not been the subject of testing or research. The judge quoted from a report on creationism by the National Academy of Sciences as an authoritative and definitive source: "Creationism, intelligent design, and other claims of supernatural intervention in the origin of life or of species are not science because they are not testable by the methods of sciences. These claims subordinate observed data to statements based on authority, revelation, or religious belief."10

INTELLIGENT DESIGN AS RELIGION

The judge applied two related tests that the Supreme Court has set forth to determine whether an action by the government is prohibited by the establishment clause. The first test is whether the act amounts to an "endorsement of religion" by "conveying or attempting to convey a message that religion or a particular religious belief is favored or preferred."11 The second test is whether the government's purpose is to advance religion or has as its primary effect the promotion of religion. ${ }^{5}$ Regarding the endorsement test, the judge concluded that, among other things, an "objective" ninth-grade student "would view the disclaimer as a strong official endorsement of religion," as would an objective adult member of the Dover community. ${ }^{2}$ To determine the purpose of the requirement of teaching intelligent design, the judge examined the statements and actions of the members of the school board, which showed that the members who sponsored the new rule had religious motivations and worked with the Discovery Institute to promote the institute's agenda of intelligent design, including arranging for science teachers to watch a Discovery Institute film entitled Icons of Evolution.

At meetings in June 2004, members of the school board spoke "in favor of teaching creationism and disparaged the theory of evolution on religious grounds." At one meeting a member said, "It is inexcusable to have a [science] book that says man descended from apes with nothing to counterbalance it," and "this country wasn't founded on Muslim beliefs or evolution. This country was founded on Christianity and our students should be taught as such." At another meeting, the same member refused to agree to purchase a biology textbook unless the board also approved the purchase of Of Pandas and People as a companion book and ultimately won the vote. When the six-to-three vote took place at the October 2004 meeting to approve the curricular change, there was no discussion of a rationale for the change.

The board members' attempt to persuade the judge that they had acted on the basis of a secular purpose was unavailing. In the judge's words, "their asserted purposes are a sham," and he noted that the board members had relied on legal advice solely from "two organizations with demonstrably religious, cultural, and legal missions, the Discovery Institute" and the Thomas More Law Center. The judge's overall conclusion was unequivocal: the effect of the school board's actions "in adopting the curricular change was to impose a religious view of biological origins into the biology course, in violation of the Establishment Clause."2

A FOURTH WAVE?

Judge Jones's strong opinion concludes the third wave of antievolution teaching activity in the United States. Even though the opinion has no force as a binding precedent outside Pennsylvania, it is so well reasoned that it is likely to be persuasive to other judges around the country, and most state legislatures and school boards will probably be strongly influenced by it. The opinion has already caused the Ohio Board of Education, for example, to reverse its 2002 mandate that 10th-grade biology classes single out evolution for "critical analysis." 12,13 The Catholic Church, through the Vatican newspaper L'Osservatore Romano, has also reacted, describing the opinion as "correct" in that intelligent design should not be taught as a scientific alternative to evolution. ${ }^{14}$ Catholic doctrine does not preclude evolution. ${ }^{14}$ As Richard C. Lewontin has noted, the real objection that many Christians have is to Darwin's theory of randomness, because it means that "rational beings capable of moral choices might never have come into existence."15 Lewontin writes:

But without such beings the concept of Redemption is unintelligible. Christianity demands, at the very least, the inevitable emergence of creatures capable of sin. Without a history of human sin, there is no Christ. 
Everything else is up for grabs. Neither the Vatican nor much of quite conventional Protestant theology demand that one take the story of Genesis 1 literally. ${ }^{15}$

In a country in which more than 50 percent of adults consistently tell pollsters that they believe God created humans in their present form within the past 10,000 years, however, there will undoubtedly be a fourth wave that will feature yet another strategy to promote creationism by questioning evolution. ${ }^{16-18}$ It looks as if this next wave will jettison the creationist and intelligentdesign baggage and concentrate exclusively on a "teach the controversy" strategy. That this controversy is one largely manufactured by the proponents of creationism and intelligent design may not matter, and as long as the controversy is taught in classes on current affairs, politics, or religion, and not in science classes, neither scientists nor citizens should be concerned.

Of course, the theory of evolution cannot answer all questions about how life emerged or how the human brain developed, nor is evolution even relevant to the question of where the original matter of the universe came from. There is plenty of room for diverse opinions and beliefs on these subjects. Alfred Russell Wallace, for example, who, simultaneously with Darwin, proposed the theory of natural selection as the engine of evolution, believed that the development of the human brain could be explained only by divine intervention. Nobel laureate John C. Eccles, in his treatise on the evolution of the human brain, was unable to account for the unique individual self and concluded: "I am constrained to attribute the uniqueness of the Self or Soul to a supernatural creation ... which is implanted into the fetus at some time between conception and birth." ${ }^{19}$ And Stephen Hawking speaks for himself and probably for most physicists when he concludes that if and when scientists are able to construct a unified theory of the universe, humans will still be confronted with the nonscience questions of why we and the universe exist, and "about the nature of God." 20

The quest to banish religion from politics and government is ultimately, as the Jesuit priest
Robert Drinan notes, "hopelessly unrealistic, because religions are by their nature intended to create cultures, even civilizations." ${ }^{21}$ Religion and government are not inherently incompatible, and they necessarily have formal and informal relationships with each other. Nor are science and religion inherently incompatible. ${ }^{22,23}$ Nevertheless, religion is not science and should not be taught in science class. In the United States, the higher power that prevents this is the First Amendment.

From the Department of Health Law, Bioethics, and Human Rights, Boston University School of Public Health, Boston.

1. Culotta E, Pennisi E. Breakthrough of the year: evolution in action. Science 2005;310:1878-9.

2. Kitzmiller v. Dover Area School District, 400 F. Supp. 2d 707 (M.D. Pa. 2005).

3. Scopes v. State, 154 Tenn. 105, 289 S.W. 363 (1927).

4. Epperson v. Arkansas, 393 U.S. 97 (1968).

5. Lemon v. Kurtzman, 403 U.S. 602 (1971).

6. Annas GJ. Monkey laws in the courts. Hastings Cent Rep 1982;12(2):22-3.

7. McLean v. Arkansas Board of Education, 529 F. Supp. 1255 (D. Ark. 1982)

8. Edwards v. Aguillard, 482 U.S. 578 (1987).

9. Bumiller E. Bush remarks roil debate over teaching of evolution. New York Times. August 3, 2005:A14.

10. Steering Committee on Science and Creationism. Science and creationism: a view from the National Academy of Sciences. 2nd ed. Washington, D.C.: National Academy Press, 1999.

11. County of Allegheny v. ACLU, 492 U.S. 573 (1989).

12. Rudoren J. Ohio expected to rein in class linked to intelligent design. New York Times. February 14, 2006:A12.

13. Idem. Ohio board undoes stand on evolution: intelligent design sustains 2nd loss. New York Times. February 15, 2006:A14. 14. Fisher I, Dean C. In 'design' vs. Darwinism, Darwin wins point in Rome. New York Times. January 19, 2006:A12.

15. Lewontin R. The wars over evolution. The New York Review of Books. October 20, 2005:51-4.

16. Holden C. Darwin's place on campus is secure - but not supreme. Science 2006;311:769-71.

17. Reading the polls on evolution and creationism. Washington, D.C.: Pew Research Center, September 28, 2005.

18. Monastersky R. On the front lines in the war over evolution. Chronicle of Higher Education. March 10, 2006:A14-A17.

19. Eccles JC. Evolution of the brain: creation of the self. London: Routledge, 1989.

20. Hawking SW. A brief history of time: from the big bang to black holes. New York: Bantam Books, 1988.

21. Drinan RF. Can God \& Caesar coexist? Balancing religious freedom and international law. New Haven, Conn.: Yale University Press, 2004.

22. Gould SJ. Rock of ages: science and religion in the fullness of life. New York: Ballantine Books, 1999.

23. Smith GP. Law, medicine, and religion: towards a dialogue and a partnership in biomedical technology and decision making. J Contemp Health Law Policy 2005;21:169-205.

Copyright @ 2006 Massachusetts Medical Society. 